\title{
Mangroves of Maputo, Mozambique: from Threatened to Thriving?
}

\author{
Ana Beja da Costa, Luis Paulo Faria Ribeiro
}

\begin{abstract}
Coastal wetlands worldwide are among the most productive yet highly threatened systems in the world, and are framed and protected by the Convention on Wetlands (Ramsar, Iran, 1971), of which Mozambique is a party since 2004 (IUCN, 1971). Maputo city coastline consists of an ample alluvial plane, where large extensions of mangrove forests occur within the city, namely the Costa do Sol wetlands, offering a wide range of ecological and economical services. Here, urban development pressure is increasing and rapidly changing dynamics are creating new urban settings, pressing in ecological sensitive areas of Maputo's coastline. The functions of the still existing ecosystems and positive effects that these can have within the urban environment are relevant to be known and investigated in light of the greenway principles. Through the landscape architecture lens, insights on the service capacity of these mangroves in terms of conservation strategies, local perception, usage and management, and design possibilities are added, which can contribute to maintain and expand the high urban quality that is historically attached to Maputo city.
\end{abstract}

Keywords: coastal ecosystems, mangroves, Maputo, sustainable urban development

From the very beginning of human settlements, the environment has shaped the cultural profile of those who inhabit it. On the one hand, humans have worked and molded the landscape, on the other hand, the surrounding environment has strongly shaped the way different cultures have developed (Ribeiro, 1960). Climate, topography, water and distance to 
fertile soil are fundamental features of a territory and dictate how men can thrive, that is coastal deltas, estuaries and alluvial plains have a large and accessible fish stock, land is more fertile and the variety of both fauna and flora species is higher.

Throughout the period of the maritime discoveries, a new form of coastal settlements was established, based on their accessibility through calm waters, clear views out to sea for defense purposes and easy access to the hinterland to secure access to resources for survival and for further territorial explorations. "As soon as humans started to urbanize and exploit these regions, and especially when urbanization, navigation, industrialization and agricultural exploitation intensified during the nineteenth and twentieth centuries, the territorial conditions of these lowlands changed fundamentally" (Meyer, 2014). Cities then continued to evolve as industrial ports, providing significant economic boosts to the income of cities and countries, yet with increasing urban challenges for the society, the environment and the economy.

Currently, and well into the twenty-first century, $40 \%$ of the world's urban population lives in coastal areas (IOC/UNESCO et al., 2011) and thus a significant amount of goods and services are obtained from coastal-marine ecosystems. According to Barragán and Andrés (2015), the number of people living in coastal cities in temperate areas is dropping, while in tropical and equatorial areas the number of coastal cities has risen from 94 to 795 , providing for 614 million people and adding unprecedented pressure on coastal-marine ecosystems.

In Maputo, the consolidation of the colonial settlement on the northern margin of the bay began in 1825 with the establishment of the Lourenço Marques commercial company. Since then, it has developed through successive plans where the planned city, also known as cimento (concrete), appeared in opposition to the spontaneity that generated the informal city, the caniço (reed) (Sousa Morais, 2001). The caniço was initially the place where natives employed by the Portuguese built their temporary cane houses. Many parts of this area of the city were organized in an orthogonal grid, a legacy from the colonial period, and were "managed using part of the indigenous experiences, knowledge and structures" (Meneses, 2014). The temporary materials used allowed for the removal of the houses whenever the formal city needed to expand. Throughout the nineteenth and twentieth centuries, the city developed in a plateau adjacent to the port, framed by successive urban plans that shaped the city with still visible marking features: the quality of the architecture, the openness of its avenues and the constant presence of trees along the streets that gave Maputo its green city image.

The post-independence processes and the civil war led to a deep cut with the colonial way of producing the city. After the 1975 socialist revolution, serving the population was the main priority. The capital should have worked as a production mechanism for the country and as a city, the goal 
was to avoid segregation and improve the city's polycentrism (Mendes, 1980). Nowadays, Maputo is Mozambique's most populated city with a projected population of 1,273,076 people in 2017 (INE, 2014), causing "destruction and fragmentation of coastal habitat” (Barragán and Andrés, 2015). Urban expansion towards the coast of Maputo is a known ongoing phenomenon and the functions of the existing ecosystems and the positive effects these can have within the urban environment need to be highlighted, disseminated and integrated into the planning process, in light of the greenway principles presented below.

\section{STATE OF THE ART}

\section{The Role of Mangrove Ecosystems for Global Ecology}

Coastal wetlands, such as the ones found in Maputo Bay, are among the most productive ecosystems in the world. They were described by Odum (1971) as "high diversity tropical coastal ecosystems," which given the small temperature and salinity changes can divert their energy to elevated symbiosis degrees, hosting complex life cycles and organism adaptation, as mangrove roots adapt to salt water; as organisms that adapt to intense luminosity and consequently produce high levels of organic nutrients; as habitats that promote and support seagrass meadows and coral reefs; and through all of these "produce disproportionately more services relating to human well-being than most other systems" (MA, 2005).

Framed and protected by the 1971 Ramsar Convention on Wetlands, of which Mozambique is a party since 2004, wetlands are the only group of ecosystems to have their own international convention (Turner et al., 1999). Since then, they have been generally defined as "areas of marsh, fen, peatland or water, whether natural or artificial, permanent or temporary, with water that is static or flowing, fresh, brackish or salt, including areas of marine water, the depth of which at low tide does not exceed six meters." Under this Convention, Recommendation 10 focuses specifically on "African Wetlands" and the value of African wetlands as habitats for migratory waterfowl in the winter. Furthermore, it recommends "research on productivity of wetlands and, possibly with the help of UNESCO, establish an African List of wetlands of international importance (...)" (IUCN, 1971). Mangrove areas worldwide play an important role in coastal and marine ecosystems. They are a nutrient-rich environment and sheltered nursery ground for marine fauna, they regulate sedimentation, prevent coastal erosion and protect the coastline from storms and high tide events (Bandeira and Paula, 2014), both by diminishing water runoff speed and by sustaining the soil. Within coastal urban contexts, mangrove forests play a relevant role as regulators of water quality and wastewater filtration. Mangroves provide important ecosystem services that go beyond mere water security and water for food security. Other ecosystem services provided by wetlands include nutrient cycling, food security (provision of crops and nurseries for fisheries), job security (maintenance of fisheries, soil quality for agriculture) and "a 
range of cultural benefits, including knowledge (scientific and traditional), recreation and tourism, and formation of cultural values, including identity and spiritual values" (ten Brink et al., 2013).

On the crucial issue of climate change (both mitigation and adaptation), mangroves can be used as indicators of sea-level rise (de Boer, 2002), mitigating elements for storm and tidal surges (and consequent changes to river flow regimes and sediment transport) (MA, 2005), and for protection against erosion. Mangroves can act as resilient storm buffers, reducing costs of infrastructural works, shifting the construction trend from "hard engineering works" to "soft engineering solutions" (Kithiia and Lyth, 2011). Mangrove ecosystems in urban coastal areas should be regarded as service providers, such as food sources, environmental protection and for fuel and material for household provisions, as well as for the construction of boats and houses. Such services have been used over time, with strong evidence among the original settlements along the coastline of Maputo, such as in Bairro dos Pescadores and Katembe, where mangroves supported people in meeting their basic needs and in improving their quality of life (Roberts et al., 2011); and as service providers, for example, for waste treatment by recycling waste components (Cilliers et al., 2013), among others. As Maputo's land resources are exhausted in the plateau, where the city was historically developed, and new investments and new urban and infrastructural projects are putting pressure on the city's coastal flood plains, wetland ecosystems need to be considered as fundamental assets in the planning processes of the newly urbanized areas of Maputo, stressing their importance in the context of resilient edges for new expanding urban areas.

\section{International Agreements and Mangrove Ecosystems}

The 1970s saw an increase in environmental awareness, as a result of a greater evidence of the irreversible impact of resource exploitation on nature. The Ramsar Convention raised awareness on the importance of wetlands worldwide, as well as on wetlands conservation and management. In 1971, the UNESCO Man and Biosphere (MAB) Programme was launched to develop a framework for sustainable use and conservation of biological diversity, improve relations between people and their environment and promote research and capacity building for natural resource management. Protected areas were established as biosphere reserves to promote sustainable community development and empower communities to better manage natural resources (UNESCO-MAB, 1971). There are currently forty-seven biosphere reserves that include mangroves (ConservationTraining, 2017).

Following the Ramsar Convention, nature conservation and sustainable use of natural resources unfolded under several agreements, reflecting directly on mangrove and other coastal ecosystems. Many endangered mangroves 
and/or endemic species can be found in the Convention on the International Trade of Endangered Species (CITES, 1975), including species that depend on mangrove ecosystems. The 1983 Convention on the Conservation of Migratory Species of Wild Animals (CMS) (Bonn Convention, 1979) aims at conserving migratory animals and their habitats, including mangrove ecosystems (UNEP-CMS, 1979), and the Agreement on the Conservation of African-Eurasian Migratory Waterbirds (AEWA, 1996) studies birds that depend on wetlands for at least a part of the year, where Mozambique is considered a "Non-Party Range State," as its wetland habitats are within the range of migratory routes (UNEP-AEWA, 1996).

The 1992 Rio de Janeiro United Nations Conference on Environment and Development and the publication of Agenda XXI, saw an increase in environmental awareness and a greater recognition of the global impacts of actions taken by the overexploitation of natural resources, climate change, inequalities and poverty within nations and between them (UN, 1992). The UN Economic Commission for Africa subsequently outlined strategies to address some of the major constraints to economic development, such as "activities of transnational corporation with high financial as well as ecological costs, the impact of the exploitation of natural resources, demographic changes and population pressures," ecosystems management and conservation, the prevention and reversal of desertification processes, and securing greater energy self-sufficiency (UNECA, 1993).

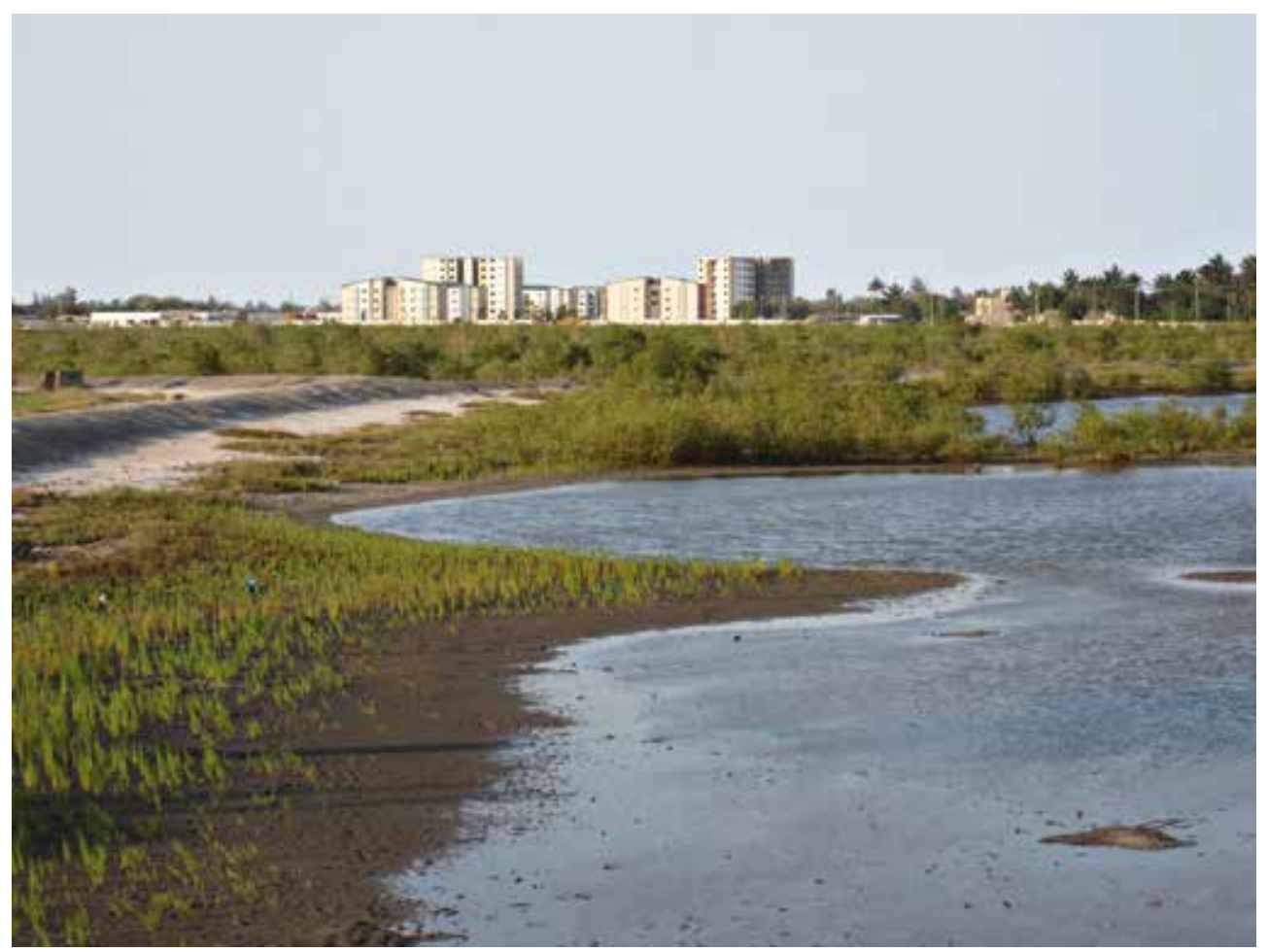

Figure 1. Progressive urbanization of Maputo's wetlands. 
These gave origin to a set of agreements such as the UN Framework Convention on Climate Change (UNFCCC, 1994), the UN Convention to Combat Desertification (UNCCD, 1994) and the UN Convention on Biological Diversity (UNCBD, 1993). The UNFCCC led to the development of the Kyoto Protocol in 1997, later the Doha Amendment (ConservationTraining, 2017) and finally the Paris Agreements in 2014 (UNFCCC, 2017). Relevant to Mangrove conservation, the UNFCCC established the National Adaptation Programmes of Action (NAPAs) as important tools to promote mangrove conservation for community resilience and security facing global climate change. Other relevant mechanisms of the UNFCCC that can be applied to mangrove ecosystems include the Reducing Emissions from Deforestation and Forest Degradation (REDD+), which recognizes the mangrove's potential as "carbon sink."

The UNCBD is implemented through the National Biodiversity Strategy and Action Plan (NBSAP) at national level and it directly implies protection of biodiversity of flora and fauna in mangroves through its Aichi Biodiversity Targets (2011-2020).

These agreements are often updated, strengthening goals, yet also shifting them, making the attainment of results difficult to achieve, as was the case with the Millennium Development Goals. The new Sustainable Development Goals have been set as ambitious yet more realistic goals, where mangroves can be inserted in the goals relating to ending hunger, achievement of food security and improved nutrition, and promoting sustainable agriculture (Goal 2); clean water and sanitation (Goal 6); making cities and human settlements inclusive, safe, resilient and sustainable (Goal 11); ensuring sustainable consumption and production patterns (Goal 12); taking urgent action to combat climate change and its impacts (Goal 13); conserving and sustainably using the ocean, seas and marine resources for sustainable development (Goal 14) (UN, 2016). Nevertheless, progress is being made in what concerns ecology and conservation. A useful tool to measure the intrinsic value of ecosystems is its translation into economic terms - the valuation of ecosystems. Ecosystem services - namely food, freshwater, energy, fiber, disease control, global climate, protection from natural disasters, non-material benefits to people (UNEP, 2005) - were acknowledged at the Eighth Conference of the Parties to the CBD (2006), as "overwhelming contributors to human life and well-being" (UNCBD, 2006). These services are provided by multi-functional landscapes, often referred to as "natural capital." The aim of the definition of the ecosystem services provided by each multi-functional landscapes is often more beneficial than the value of the converted systems, but its under-valuation is difficult to express as most of the benefits are not captured in conventional economic analysis (de Groot, 2005).

More recently, the 2013 Supplement to the 2006 International Panel on Climate Change Guidelines for National Greenhouse Inventories: Wetlands 
(the "Wetlands Supplement") specifically addresses mangrove forests and coastal wetlands, considering them "blue carbon" sinks in national GHG inventories, making up for the gaps on wetlands in the 2006 IPCC Guidelines (ConservationTraining, 2017). As healthy ecosystems are increasingly being recognized for their capacity in increasing resilience to climate change and helping people to adapt to changes through the delivery of many ecosystem services, the Hyogo Framework for Action 2005-2015: Building Resilience of Nations and Communities to Disasters (Hyogo, 2005) and the Post-2015 Disaster Risk Reduction Framework provide global guidelines for disaster risk reduction through a series of priority actions. Coastal resilience to disasters and to global change are directly linked to mangrove ecosystems, and must be integrated into coastal planning and management as fundamental elements in coastal protection and for the development and sustainability of local livelihoods.

Since 1974, the UNEP Regional Seas Programme addresses the degradation of the world's oceans and coastal environments through its sustainable management and use, by engaging neighbouring countries in actions aimed to protect their shared marine environment. The East Africa Region is under the scope of the Nairobi Convention (Nairobi, 1985), having entered into force in 1996, and its implementation notes Mozambique's vulnerability to interests in exploring potential gas reserves that may "exacerbate the destruction of critical habitats such as coral reefs, mangroves, beaches and sea grass meadows" (UNEP-RSP, 2010). Recently, the UNFCCC reached a landmark agreement in the twenty-first UN Climate Conference in Paris (COP, 21), hopefully shifting the course of two decades of global climate efforts. The recent agreements end the strict differentiation between developed and least developed countries, and require that all parties report on their emissions and implementation efforts for review.

\section{Mangrove Management: Good Practices}

Many tropical cities across the world are experiencing urban growth that is compromising the carrying capacity of their coastal ecosystems due to the depletion of groundwater supplies, aquifer and sea water contamination by urban wastewater and industrial pollution, and saline intrusion. Moreover, groundwater extraction and heavy construction load can lead to ground subsidence, as is the case in some areas of Jakarta (Dsikowitzky, 2016). Additionally, land reclamation for human settlements, such as in Lagos (Agboola, 2016), is fragmenting previous mangrove forests into disconnected patches. This section of the paper presents good practices in mangrove management and although some of these are not in the urban context, they offer important lessons learned for coastal cities.

In the Indian Sundarbans, where mangrove ecosystems are in distress, given pressure exerted by densely populated rural areas, a comparative 
study of soil-plant-water relationships in two sites assessed the level of success of a restoration process managed by an NGO and of an unmanaged site (Datta, 2017). During the 1990s, small-scale, but generalized logging was practiced by the villagers; from 1995 onwards the NGO and local administration began to involve locals in participatory management activities and protection actions from illegal logging, such as monitoring, replanting and building fences for new planted seedlings and removing litter (Datta, 2017). In return, villagers received a major share of the income generated by this ecosystem. The study concluded that after the initial ten to fifteen years, although community-based management had not been fully efficient in mangrove regeneration, results were better than in the legally, but non-managed protected reserve (Datta, 2017). It shows that long-term community-based management, with monitoring, protection and use of mangroves in a sustainable manner, is more efficient than not taking action and waiting for natural regeneration as nearby villages deplete forest coverage for economic and domestic purposes.

The PUMPSEA Project (Peri-urban mangrove forests as filters and potential phytoremediators of domestic sewage in East Africa) aims to demonstrate "the ecological and economical service that peri-urban mangroves provide by mitigating coastal pollution through sewage - filtration, offering innovative solutions for the exploitation and management of this quality," (PUMPSEA, 2008) through the means of constructed wetlands in three case study areas in the following cities: Maputo (Mozambique), Dar es Salam (Tanzania) and Mombassa (Kenya). The conclusions included that the use of replanted and rehabilitated mangroves for sewage treatment may have a lower cost than conventional sewage treatment systems and that such considerations should be considered in Coastal Zone Management Plans, particularly in those with multiuse approaches (PUMPSEA, 2008). In Uganda, the Government launched a policy that focuses on wetlands outside protected areas, as is the case in urban and peri-urban wetlands. It is the first policy of this kind in Africa and is a clear response to the recommendations of the Ramsar Convention (Kabii, 1997).

The best practices here presented all have a common conclusion that legal protection of mangrove ecosystems is not effective unless there is close cooperation between government, NGOs and the public; additionally, these need to be fostered as part of a long-term strategy (Agboola, 2016), for protection and management of coastal wetlands.

\section{MAPUTO: A CASE STUDY}

\section{Methodology for Mangrove Spatial Analysis in Urban and Peri-Urban Settings}

To map and analyze land use evolution and the state of coastal ecosystems in the specific case of Maputo, the Landscape - System method (Magalhães et al., 2007) was adopted. 
This method feeds on the basic principles of the lan McHarg's method that separates different territorial layers, revealing underlying ecological systems and the connections between the different elements that compose them. McHarg's approach became well established in his book Design with Nature (1969), whereby through the presentation of several case studies, he applies the method by overlapping physiographic constraints maps to identify critical zones for infrastructure construction and urbanization, or by overlapping different aptitude maps to define the areas that are most favorable for different human activities (urbanization, industry, agriculture, etc.), always in an anthropocentric perspective and with the common goal of "orienting a positive pattern of development" (McHarg, 1969).

Ribeiro Telles defends the Continuum Naturale (Natural Continuum) principle, based on the concept of structure in its ecological and cultural terms, "which establishes the connection between urban and rural (or natural) landscape, bringing rural and urban populations closer in a balanced inter-relation between people and landscape;" and it adds that the "global landscape will be subjected to its own biological essence and, as such, the location of activities, including urban expansion, has to be subjected to territorial aptitude and the existing landscape" (Telles 1994, in Magalhães, 2001), thus reinforcing McHarg's approach, adding to the notion of balance between rural and urban, and that of man and nature. This concept is generalized as Greenways, stemming from Forman's (1990) ecological principles of "patch and corridor," which takes into account the need for linkage infrastructures that "connect isolated natural areas that remain in an increasingly fragmented megapolitan landscape" (Ahern, 1995). Though greenways have many definitions worldwide,

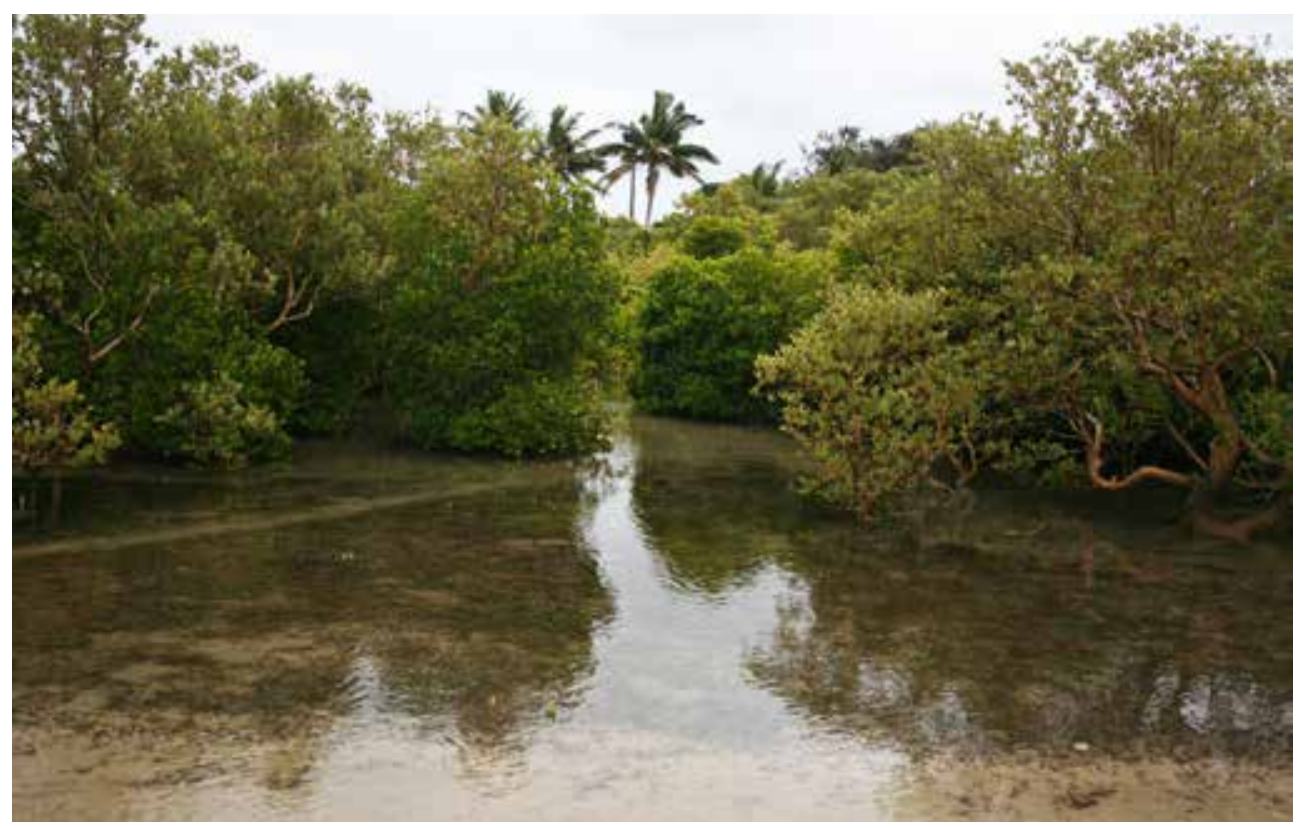

Figure 2. Mangroves at Inhaca Island, Maputo. 
Ahern (1995) describes them as "networks of land containing linear elements that are planned, designed and managed for multiple purposes including ecological, recreational, cultural, aesthetic, or other purposes compatible with the concept of sustainable land use." The Landscape System method takes landscape planning basic concepts, such as the Continuum Naturale and "Ecological Aptitude," adding the complexity and systemic thought notions to McHarg's method, assuming that the ecological auto-regulation capacity of the landscape depends on the maintenance of energy flows through continuous structures (Magalhães et al., 2007), which set the basis for urban greenways.

Based on the previous concepts, a cartography catalogue was developed to characterize the Maputo Municipality, compiling existing and new cartography in a common format so that these may be overlapped, informing how we can extract information for the delimitation of areas suitable for potential mangrove establishment, as well as for its conservation. It is also important to mention that this method can contribute to the definition of non-aedificandi areas [upon which one cannot build] along the coastline, intrinsically related to the areas for (and of) mangrove habitats, not only because of the disturbance to these ecosystems, but also because of flooding risk, groundwater contamination and public health risks that these areas are prone to when urbanized. Again, as referred to by McHarg, the constant basis of these methods is "that nature is an interacting process, a seamless web, that is responsive to laws, that constitutes a value system with intrinsic opportunities and constraints to human use" (McHarg, 1969). As Favaro states in her PhD thesis, "mapping offers a way to deal with complexity, an opportunity for extracting a synthesis image from a complex interpolation of different specific knowledges, coming from different fields, regarding the territory. In this sense, mapping allows designers and planners not only to reveal contradictions and possibilities in the complexity of the territory under design, but also to recognize its potential. In unfolding complexity, mapping is a fundamental tool in urbanism practice" (Favaro, 2017).

[...] historical geology, climate, physiography, the water regimen, soils, plants, animals and land use. This is the source from which the interpretation is made although the grain becomes finer.

(McHarg, 1969)

To understand Maputo's landscape, geology and topography were the first step for the cartographic interpretation (Momade, 1995). Several maps were generated from the Aster Global Data Elevation Model (Copyright METI and NASA) to better characterize Maputo's landscape, including hypsometry and slopes. A hydrology map was obtained through the Cenacarta (National Cartography and Remote Sensing Centre) of the Ministry of Agriculture in Mozambique. Through these maps, one can have an overview of the original landscape - topoclimate - and the dry 
and wet systems, in order to understand water behavior that influences soil formation and the type of vegetation developing. Secondly, how the areas of natural risk and environmental impact can be assessed in the development of the city's infrastructure and urban tissue (Tomás de Oliveira et al., 2012).

Finally, to obtain an overall analysis of the evolution of mangrove areas and land use changes in the Maputo Municipality over the past decades, a comparison between the 1965-1967 Maputo District Military Map (DPSGC, 1967, 1965, 1958b, a) and the 2017 ESRI ArcGIS (Esri, 2017) base map provided an overview of land use changes over the past fifty years. The precise analysis of land use variation can support the ecosystems and urban development evolution trends and identify conflicts by quantifying and associating each figure to precise locations within the Municipality, specifically in the coastal areas that are within the research scope.

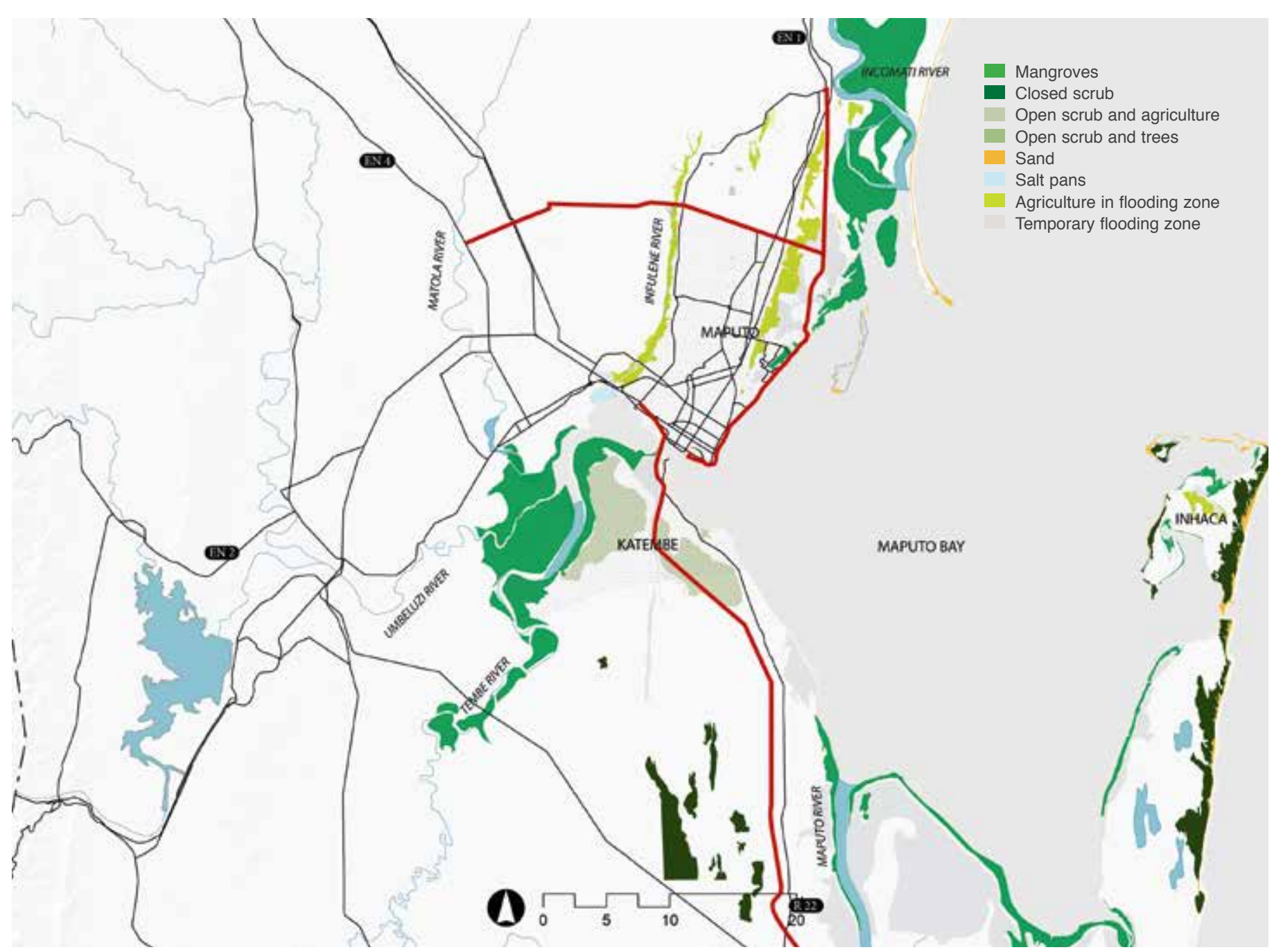

Figure 3. Maputo city location and major roads in relation to hydrography and coastal ecosystems of Maputo Bay. 
Biophysical Characterization of Mangrove Areas in the Study Areas: Bairro Dos Pescadores, Katembe and Inhaca

There are several relevant wetland ecosystems in the Municipality of Maputo, such as mangroves, sand dunes and seagrass meadows. The mangrove ecosystems of Maputo Bay occur from the northern border of the Municipality, in the low-lying plain between the Ponta Vermelha ridge and the sea to the flood plain at the mouth of the Incomati River. The floodplain holds a considerable area of mangrove forest that has been progressively fragmented by urban development, namely in Bairro dos Pescadores. Mangroves reoccur in the southern margin of Maputo's Municipality, in Katembe, on the right margin and mouth of the Tembe River; in Inhaca Island, they occur in the North and at Saco da Inhaca bay (Fig. 3).

A clear cut across Maputo's coastal landscape shows the geological fracture between the "Ponta Vermelha" Formation (TPv), with the oldest geological formations of iron-rich sandstone and red sands. It has a depth of $20 \mathrm{~m}$ [66 ft.] and goes from Maputo to Marracuene, in the North, in a 3 to $4 \mathrm{~km}$ [1.9 to $2.5 \mathrm{mi}$.] wide plateau with a SW-NE orientation (Tomás de Oliveira, Momade, and Ferrara, 1996). Between the plateau and the sea there is an accumulation of silty and sandy alluvial soils (QXf and $\mathrm{Qa})$, associated to the Incomati river terraces (Tomás de Oliveira et al., 2012:23). This clearly defines the topography and consequently, the hypsometry and slopes of the area, with heights ranging between 10 and $60 \mathrm{~m}$ [33 and $197 \mathrm{ft}$.] in the plateau, with 5 to $12 \%$ slopes, while in the alluvial plain heights vary between 0 and $10 \mathrm{~m}$ [0 to $33 \mathrm{ft}$.] and slopes are 0 to $5 \%$, almost flat and thus subject to seasonal flooding. In the ridge between the plateau and the plain there is a steep slope of more than $25 \%$, where erosion-related problems are often reported.

In the Southern margin of the bay lies Katembe, which is mostly from the Congolote formation (QCo), of interior fixed dunes. Towards the coastline the Machava Formation (QMc) consisting of sandy and silty alternations, it marks the line towards the alluvial deposits of fine sediments of clay and silt (Saranga et al., 2008). Here, the Machava and Congolote formations are at a height of 10 to $20 \mathrm{~m}$ [33 to $66 \mathrm{ft}$.], whereas the heights of the alluvial deposits $(\mathrm{Qa})$ at the mouth of Tembe River and of the seaside range between 0 and $10 \mathrm{~m}$. Slopes are more homogenous than in the Northern side of the bay and vary between 0 and $12 \%$.

Inhaca Island, also part of Maputo's Municipality, is formed from east to west by the Eastern dunar string, with heights up to $115 \mathrm{~m}$ [377 ft.] (Qmd) and slopes above 25\%. The central part of the island has parabolic dunes and coastal dunes (QDO and QDOr), and the western side of the island alternates beaches, sandbanks (Qpb), intertidal plains and areas of mangrove (Qpm) (Tomás de Oliveira et al., 2012), with heights ranging between 0 and $10 \mathrm{~m}$ and slopes between 0 and 12\% (Fig. 4). 
By overlapping these maps, one can infer that mangroves (as shown in Figure 4d) develop in alluvial and/or intertidal plains. They occur where silty and clay soils deposited by river discharge and where there is a strong tidal influence. Due to the geology and geomorphological processes that influence these intertidal planes, the formed flat areas have several common characteristics, such as very low heights of no more than $5 \mathrm{~m}$ [16 ft.] above sea level and slopes of no more than 5\%. Figure 4d also shows the overlap of mangrove areas in the 1967 Military Map land use interpretation with the 2017 Esri satellite image, in which urban development is visibly compromising and scattering the original (or future potential) mangroves at Bairro dos Pescadores (Fig. 4d, square 1) and Katembe (Fig. 4d, square 2). Inhaca's mangroves may be seen as a control case study as urban and tourism developments are yet to generate pressure here (Fig. 4d, square 3).

For a better understanding of these areas, land use interpretation maps were made and analyzed, comparing land use in 1967 and its current situation in 2017. In 1967, the consolidated urban area was the Maputo colonial city and the remaining territory was occupied by disperse settlements, agriculture and scrub. In the coastal plain of Costa do Sol, land use alternated between mangroves, flooding areas and sand dunes, with only a few disperse settlements (Fig. 5). Katembe had disperse settlements and along the right bank of the Tembe River, there was a considerable area of mangrove. Scrub was the main vegetation in the dry plain adjacent to the flood plains.

Within a period of fifty years, most of the territory of the Northern margin of Maputo bay became consolidated urban area. In the coastal plain, urban area with non-consolidated urban tissue can be found, occupying the former sand dunes and temporary flood areas. The flood areas that remain free of urbanization are occupied with agriculture and the existing mangroves have their edges being reclaimed. In Katembe the settlements remain disperse, but with a greater density, with an increase of agriculture, that replaced scrubland. Inhaca Island remains stable in terms of land use when comparing the two maps. Shifts in the location of mangroves and dunes are related with both natural geomorphological processes and anthropogenic influence and, of course, due to the precision in the interpretation of the base maps (Fig. 6).

\section{MAPUTO'S COASTAL ECOSYSTEMS: TOWARDS A POTENTIAL GREEN INFRASTRUCTURE}

By overlapping the 1967 and the 2017 land use maps and crossing information, we can observe how Maputo's land use has evolved over the past fifty years, tracing previous and current uses within Maputo's Municipal area (Fig. 7). 

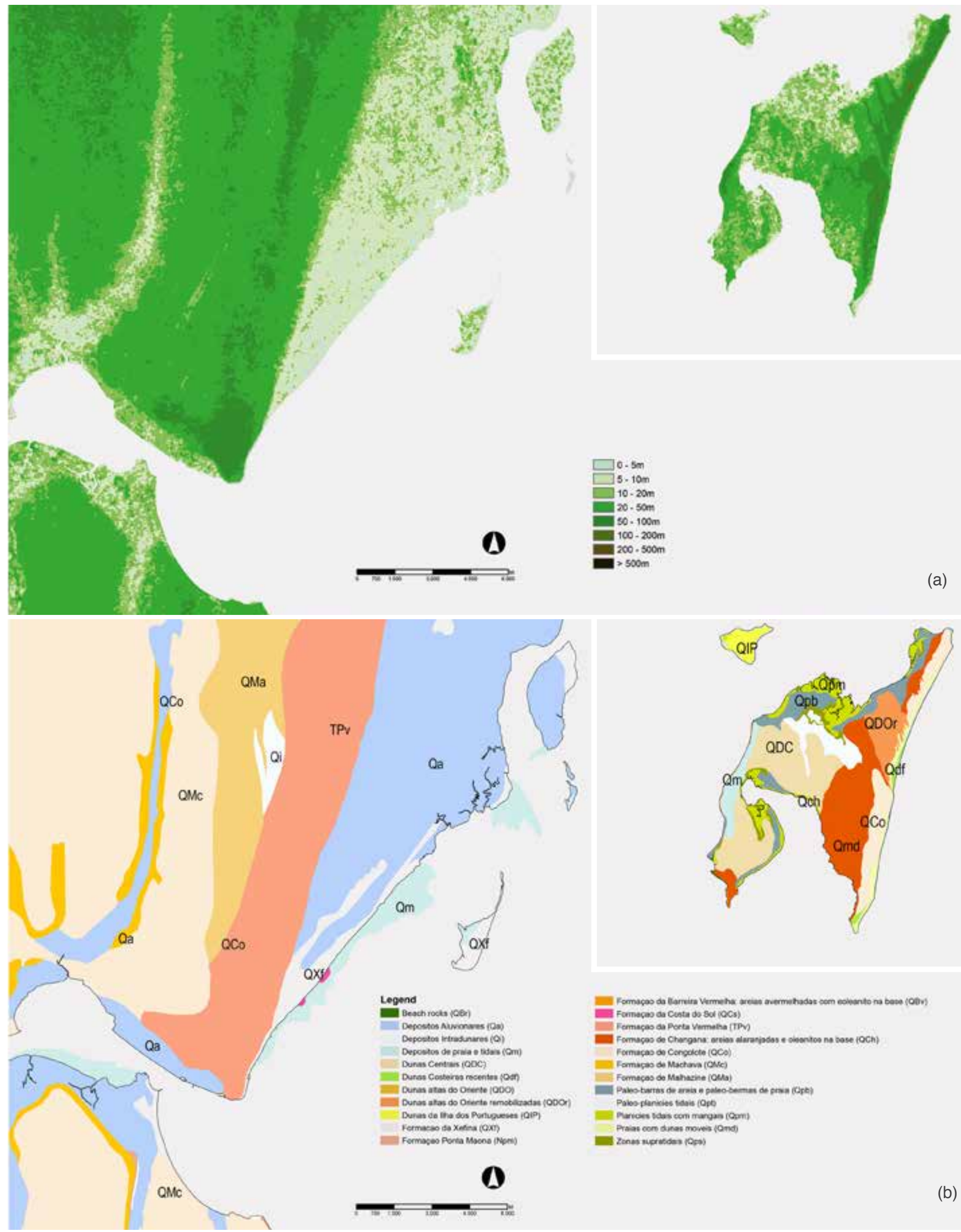

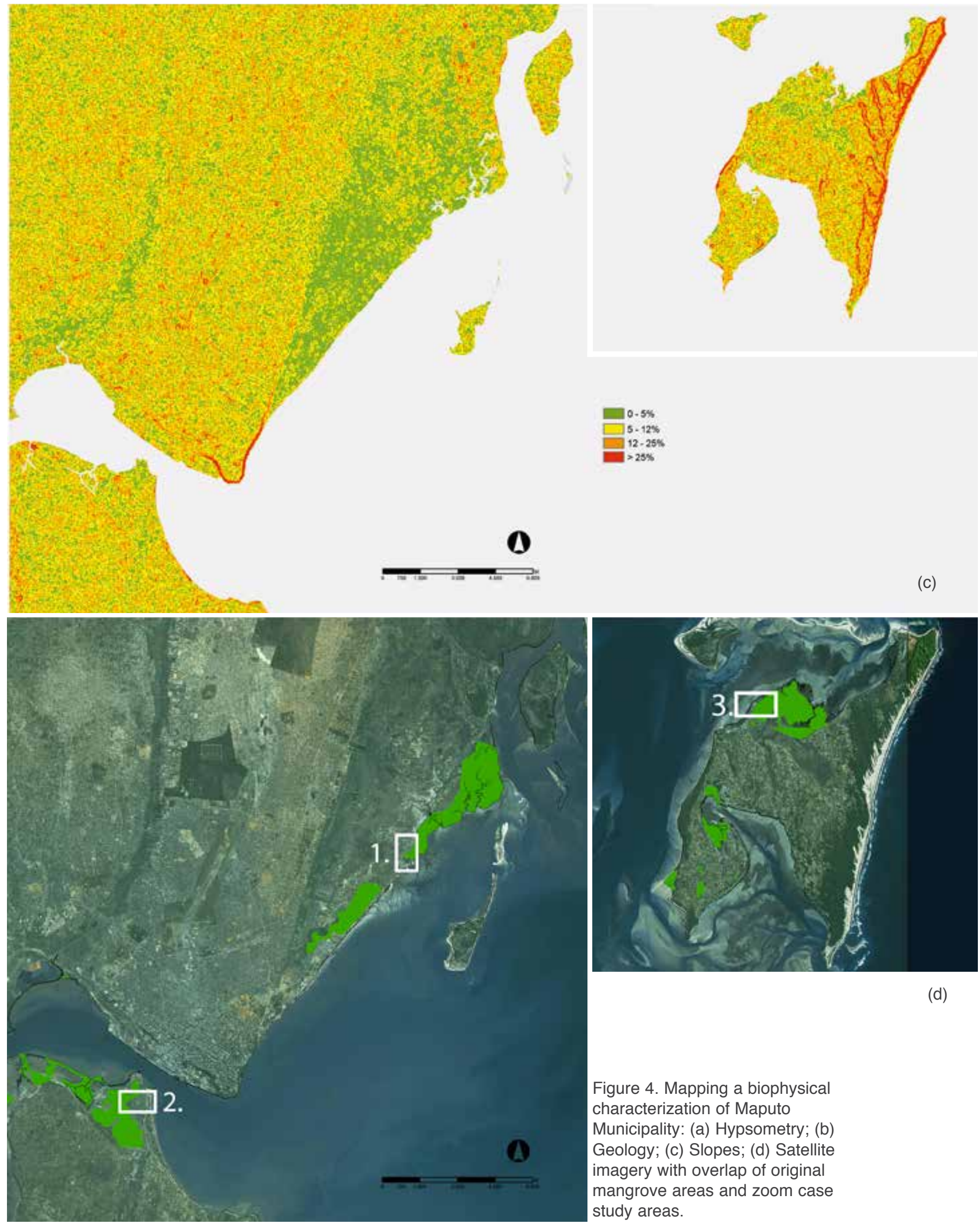

(d)

Figure 4. Mapping a biophysical characterization of Maputo

Municipality: (a) Hypsometry; (b) Geology; (c) Slopes; (d) Satellite imagery with overlap of original mangrove areas and zoom case study areas. 

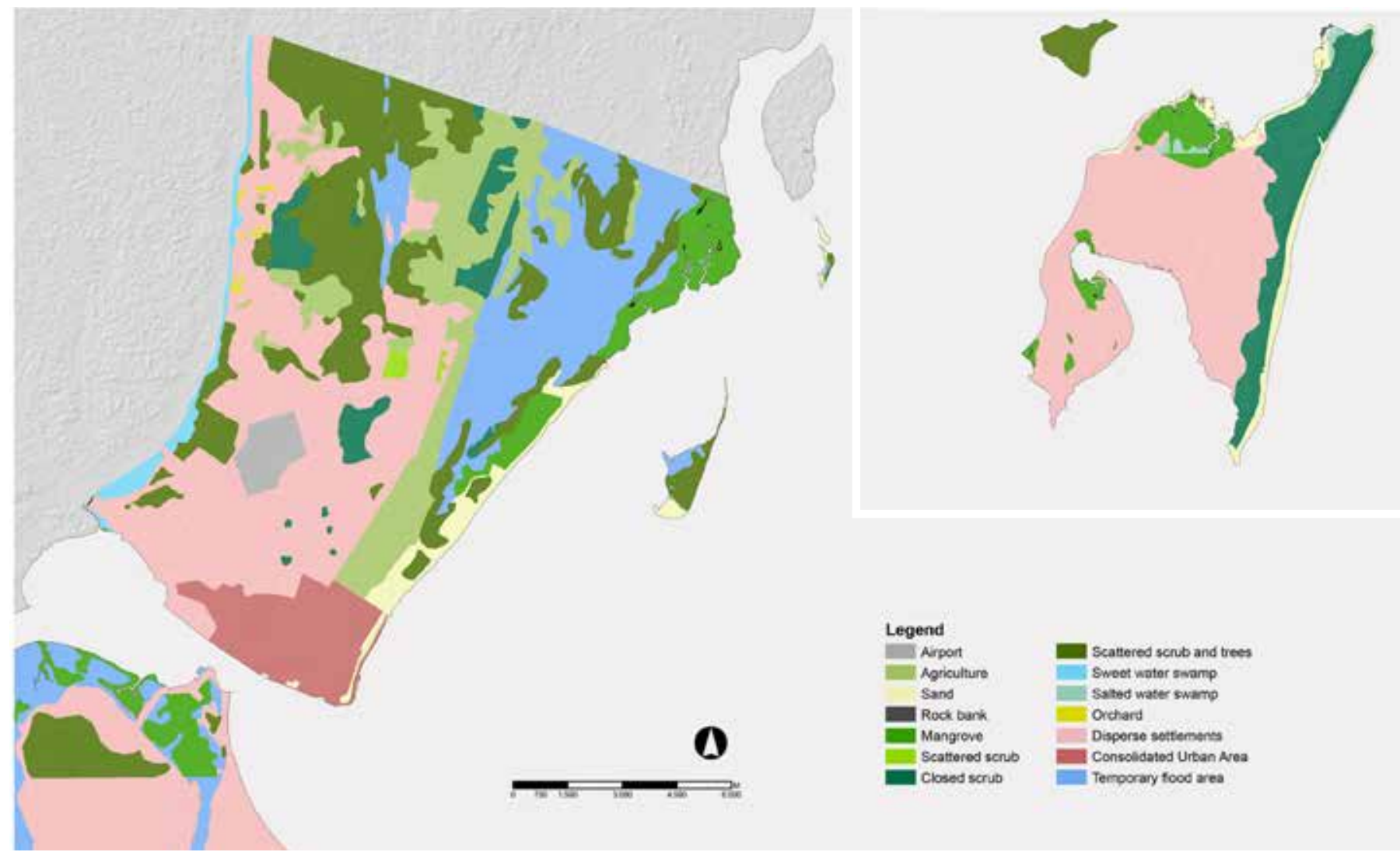

Figure 5. 1967 Land use interpretation based on 1967 Military Map of Maputo.
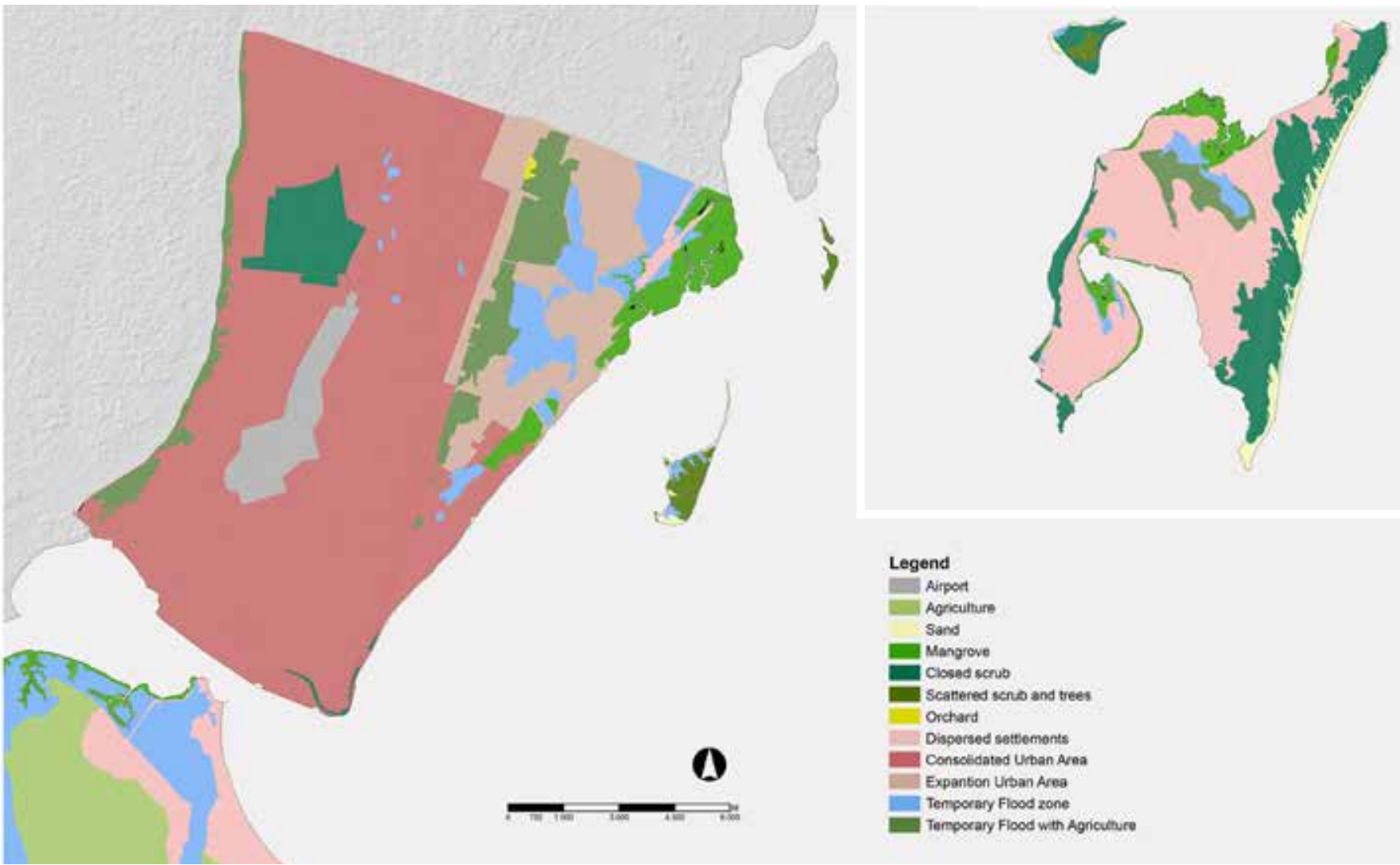

Figure 6. 2017 Land use interpretation based on satellite imagery. 
In the north side of Maputo, we can observe that the new consolidated urban areas in the plateau and towards the East coast derive from disperse settlements (see Figure 5, dark pink), agriculture areas (see Figure 5, brown) and scrub and trees areas (see Figure 5, light violet). In Katembe, disperse settlements have remained and the area occupied by agriculture has increased.

In what concerns its coastal ecosystems, and focusing on the mangrove ecosystems and temporary flood areas, we can observe how these areas have changed in relation to each other (Fig. 8), as mangrove areas deteriorate and become flooding areas; as temporary flood areas are occupied by other uses, new flood areas appear.

Always in the North, Maputo's urban development is taking over the Costa do Sol alluvial plain. There are areas of mangrove lost to consolidated urban areas (see Figure 8, dark red) at Costa do Sol and at Bairro dos Pescadores; others have been lost to reclamation but have no current use (see Figure 8 , orange). The temporary flood zones that accommodate seasonal tropical storm floods and tidal variations are progressively being used for agriculture, as people cultivate for subsistence and to sell, and are also being occupied by formal and informal low-density urban expansion (see Figure 8, dark pink), tourism facilities and infrastructure, as is the case of the Marginal de Maputo ring road. At Katembe, a large extension of mangrove area has been lost to infrastructure development, whereas most of the temporary flood zone remains the same. Finally, at Inhaca, there are considerable patches of mangrove that have been lost in the Northwest side of the island (see Figure 8, orange) and flood areas that have become agricultural areas, possibly due to the progressive population increase (see Figure 8, olive green) and subsequent increase in demand for food production areas.

By quantifying areas in percentage of the total area of the municipality, both in 1967 and in 2017 (Fig. 9), we can observe that mangrove areas in Maputo's Municipality have surprisingly decreased by only $1 \%$ over the past fifty years, from 5 to $4 \%$ of the global area, lost to temporary flood zones (where mangrove is degraded) at Katembe and Inhaca, and lost to consolidated urban areas and urban expansion in Maputo. Temporary flood zones have decreased from 13 to $8 \%$, whereas agriculture has risen from 8 to $15 \%$ of the total area, contributing to the temporary flood zone decrease and scrubland decrease (20 to $8 \%$ ). The main driver of land use change is definitively urban expansion, with an increase from 4 to $37 \%$ of consolidated urban areas, in part, substituting the dispersed settlements that decreased from 46 to $17 \%$ of the total area.

It was stated by de Boer (2002) that the mangroves in the Maputo Municipality have decreased by $90 \%$ in the Maputo city area, $49 \%$ in the Katembe area, $85 \%$ in the Costa do Sol and $22 \%$ in the Bairro dos Pescadores, between 1958 and 1991, showing a clear negative evolution in the Western margin of the bay, caused by direct use, exploitation, 


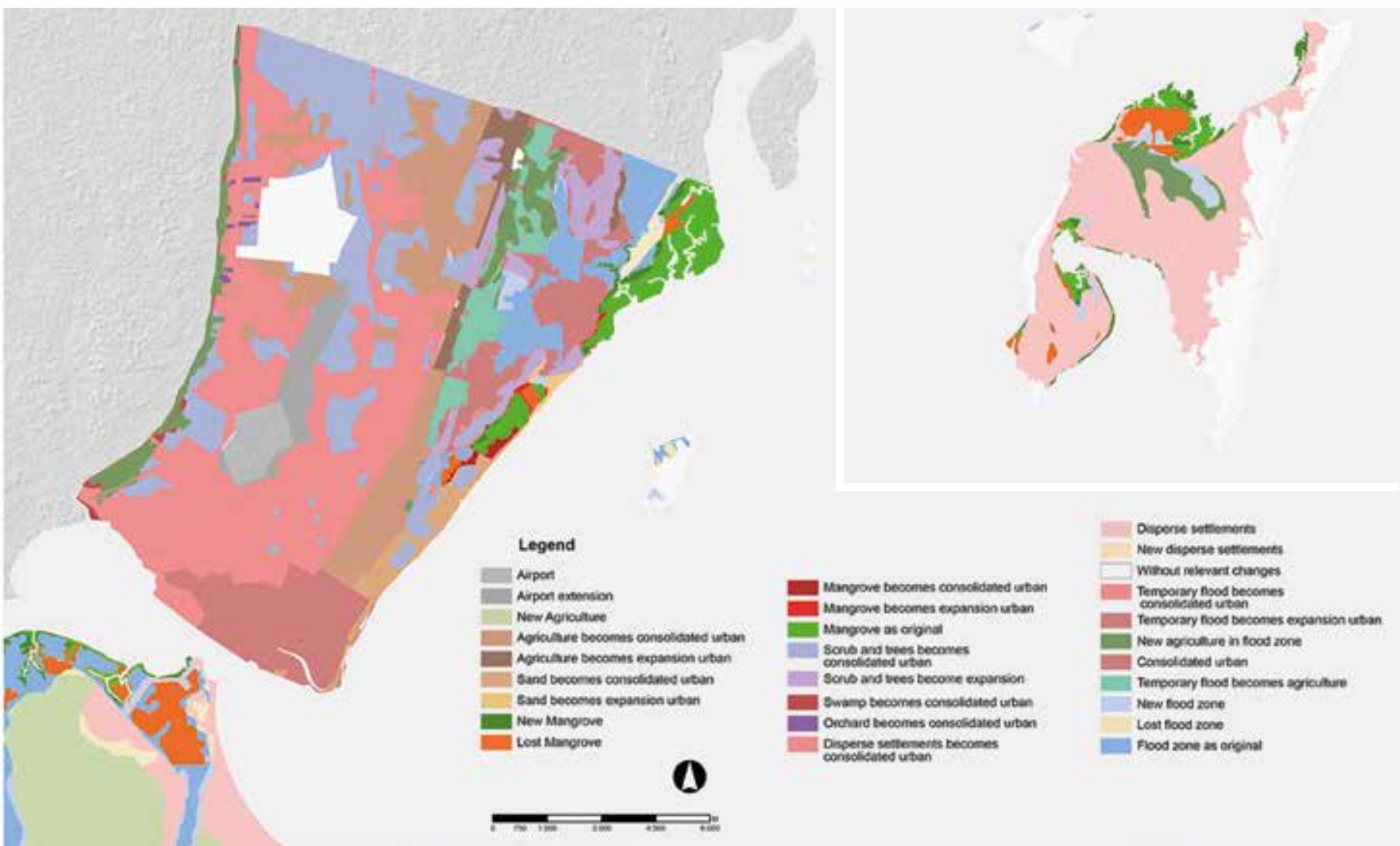

Figure 7. Maputo's land use evolution analysis for the past fifty years.

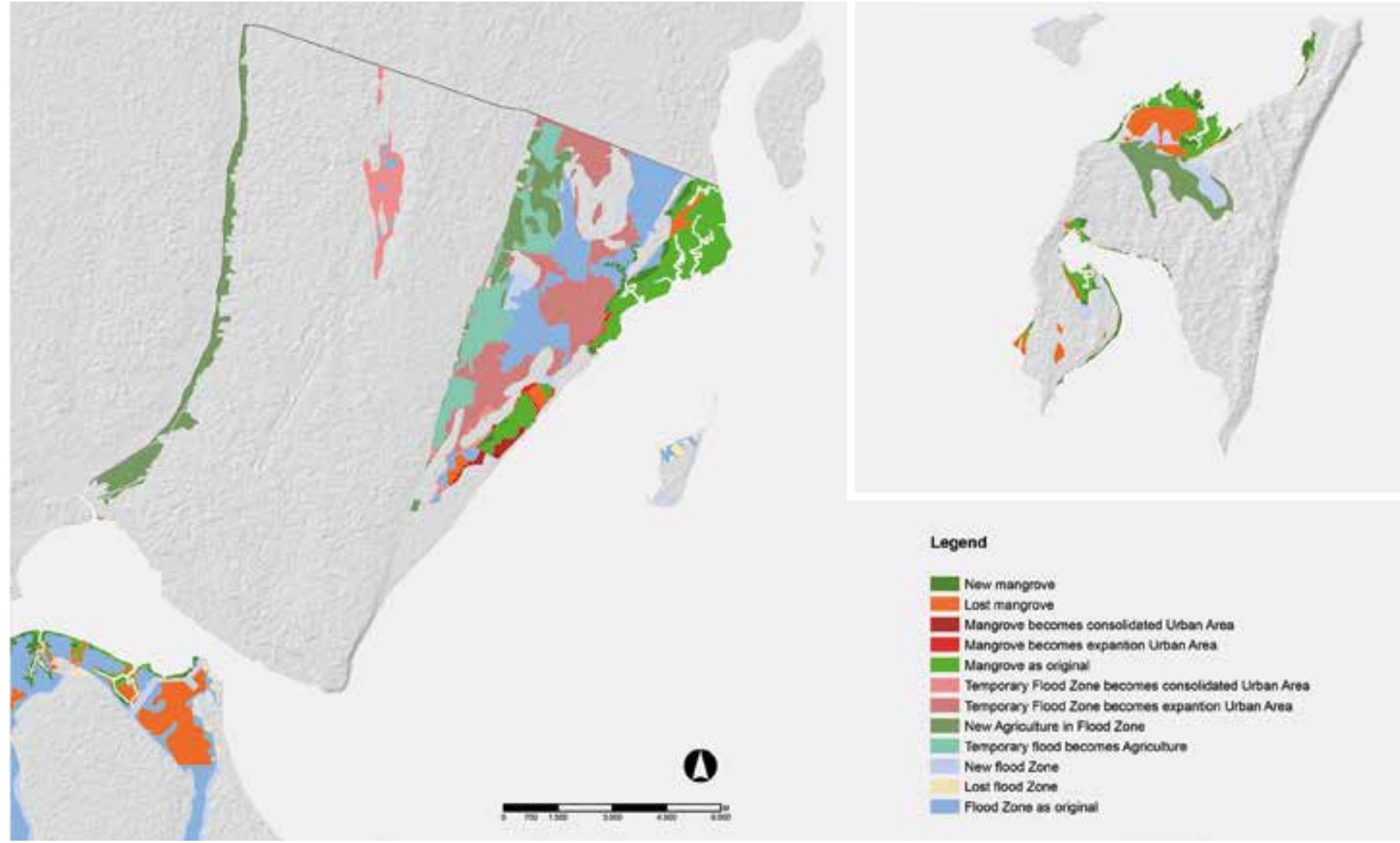

Figure 8. Maputo's coastal ecosystems evolution analysis for the past fifty years. 
and urban and infrastructure development. However, in other areas, he states that mangrove patches were actually increasing, counterbalancing the overall total area of mangrove (de Boer, 2002). The present spatial analysis shows a slight decrease of mangrove areas, yet at a lower rate than expected. It presents different figures that derive from different base imagery sources and overall area and methodology of analysis.

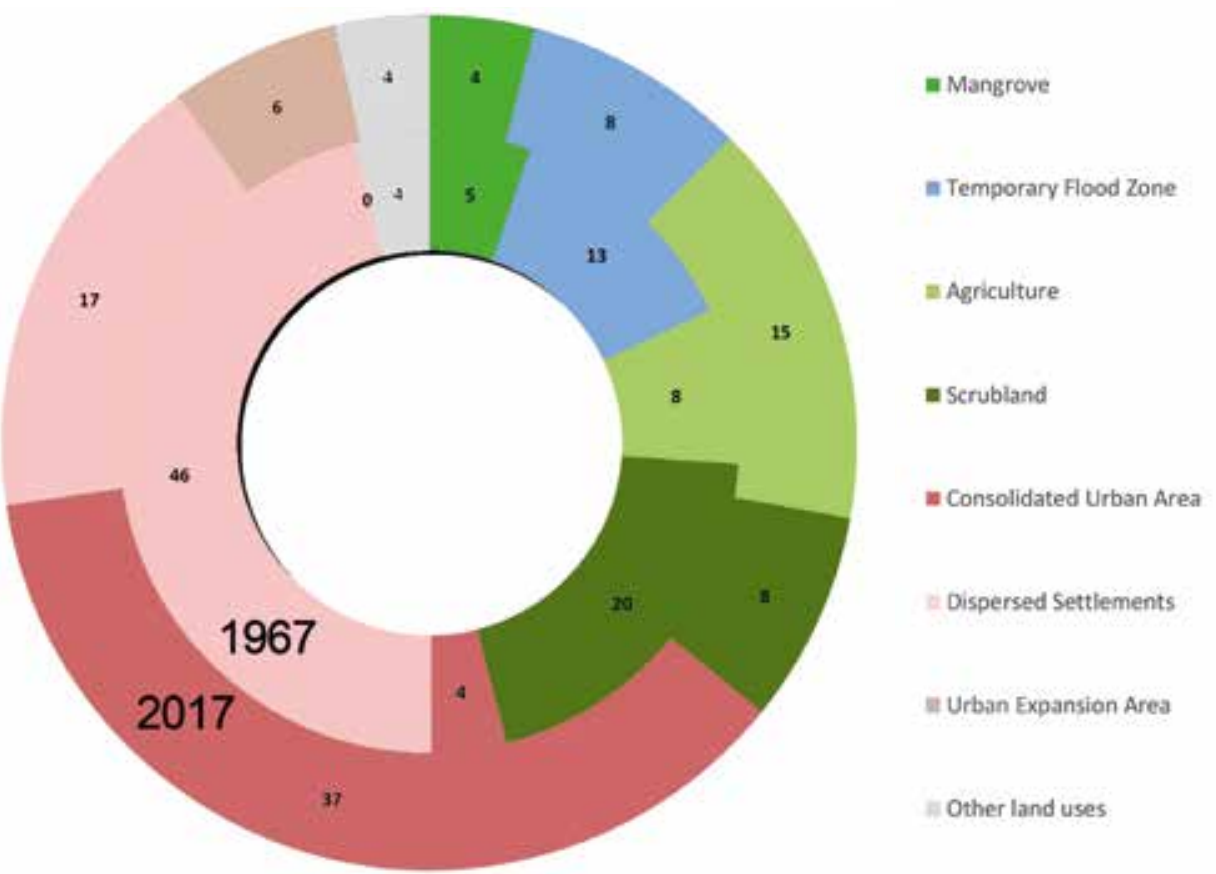

Figure 9. Land use percentages in 1967 and 2017.

\section{CONCLUSION}

Currently, coastal cities in Africa face enormous environmental challenges related to the sustainable use of natural resources and other global issues, such as climate change. However, these are not treated as priorities by local authorities and are thus not addressed in an effective manner, although there is an awareness of "what should be done."

Maputo is no exception, but it has unexplored opportunities in what concerns the state of its coastal ecosystems. The presented spatial analysis process helped quantifying land use changes, confirming that the major transformation is from "other land uses" or from "disperse settlements" being transformed into "consolidated urban area." The analysis also demonstrates that mangrove areas are not necessarily decreasing and that temporary flooding areas and agricultural areas (previously flooding areas) exist in considerable amounts at Bairro dos Pescadores, Katembe and Inhaca. There is an opportunity to preserve them as structural elements of the city and, along with them, preserve a great deal of the 
territorial capacity for auto-regulation in terms of biodiversity, carbon sequestration, pollution filtering and accommodation of flood and storm events, i.e. its ecological services. Acknowledging that "wetland value appears to be maximum when distributed spatially across a landscape that is not dominated either by cities or agriculture, but one that balances nature and human enterprises" (Mitsch and Gosselink 2000), there is an urgent need to educate and change the perception and understanding of decision-makers, stakeholders and of local communities, on the value of such ecosystems.

The mangroves and flooding areas, now perceived as leftover spaces or land waiting for real estate speculation, should be seen as fundamental assets: as greenways for the expanding city. This requires coherent strategic planning, design, public participation and awareness raising campaigns, all of which need to be recognized as priority actions by the local authorities.

Design wise, to work on the transition interface between natural coastal areas and the pressing urban areas (see Figure 8, red and orange) could be an efficient (and economic) way to demarcate and improve perception of natural areas, maintaining the ecosystems connected and functioning, while improving living conditions on the edge - between the sprawling neighborhoods and the mangrove ecosystem. Unhealthy and neglected areas can become thriving urban parks and agricultural areas, consequently improving the quality of life of the adjacent communities.

In Maputo, close attention needs to be paid to land use trends as well as to the need to overcome both the lack of operational means to implement the abovementioned strategies and the imminent pressure of property speculation at all scales and at all levels - from the political class, real estate promoters and private investors to low-income local community leaders and population. The speed of environmental sustainability implementation processes is currently far slower than the speed of population influx to these areas and of land use conversion into consolidated urban areas, indicating that if action is not taken, these ecosystems will disappear. In practical terms, the system-landscape method and further detailing the land use cartography is a rational and efficient tool that takes part in the future process of urban greenways delimitation and planning, aiming at the wider context of the Sustainable Development Goals.

Lastly, future research needs to refer to the need to fill the knowledge gap in what concerns the inclusion of healthy and productive mangrove ecosystems in urban contexts, especially in African cities, where they are being engulfed by urban sprawl and where the greenway principles need to be promoted urgently. In this context, Maputo represents an outstanding case study for the establishment of a greenway network in African coastal areas given its unique urban dynamics and existing natural capital. 


\section{References}

Agboola, Julius I., Prince E. Ndimele, Shakirudeen Odunuga, Adeniran Akanni, Bosede Kosemani, and Michael A. Ahove. "Reprint of Ecological Health Status of the Lagos Wetland Ecosystems: Implications for Coastal Risk Reduction." Estuarine, Coastal and Shelf Science 183 (2016): 340-348. doi: 10.1016/j.ecss.2016.11.022.

Ahern, Jack "Greenways as a Planning Strategy." Landscape and Urban Planning 33 (1995): 131-155. doi: 10.1016/0169-2046(95)02039-V.

Bandeira, Salomão, and José Paula, eds. The Maputo Bay Ecosystem. Zanzibar, Tanz.: Western Indian Ocean Marine Science Association (WIOMSA), 2014.

Barragán, Juan Manuel, and Maria de Andrés. "Analysis and Trends of the World's Coastal Cities and Agglomerations." Ocean \& Coastal Management 114 (2015): 11-20.

Cilliers, Sarel, Juaneé Cilliers, Rina Lubbe, and Stefan Siebert. "Ecosystem Services of Urban Green Spaces in African Countries - Perspectives and Challenges." Urban Ecosystems 16, no. 4 (2013).

Convention on the International Trade of Endangered Species (CITES). https://www.cites.org/. ConservationTraining. "Summary of Regional and International Agreements."

Datta, Debajit, and Shovik Deb. "Forest Structure and Soil Properties of Mangrove Ecosystems under Different Management Scenarios: Experiences from the Intensely Humanized Landscape of the Indian Sunderbans." Ocean \& Coastal Management 140 (2017): 22-33. doi: 10.1016/j.ocecoaman.2017.02.022.

de Boer, W.F. "The Rise and Fall of the Mangrove Forests in Maputo Bay, Mozambique." Wetlands Ecology and Management 189 (2002): 313-322.

de Groot, Rudolf. "Function-Analysis and Valuation as a Tool to Assess Land Use Conflicts in Planning for Sustainable, Multi-Functional Landscapes." Landscape and Urban Planning 75 (2005): 175-186.

de Oliveira, José T., Ruben P. Dias, Aurete Pereira, and Gabriel Balate. "Para que serve uma carta geológica: o exemplo da carta geológica de maputo." In Cooperação entre Portugal e Moçambique na área das Geociências: 1986-2012, edited by Laboratório Nacional de Energia e Geologia (LNEG), 32-35. Amadora, Port.: LNEG, 2012.

- - , F. J. Momade, and M. Ferrara. Notícia explicativa da carta geológica 2532 D3 Maputo (escala 1:50.000). Maputo: Ministério dos Recursos Minerais e Energia, Direcção Nacional de Geologia, 1996.

Direcção Provincial dos Serviços Geográficos e Cadastrais (DPSGC). Catembe Moçambique. In Carta de Portugal 1:50.000 (1958).

-- , Ilha dos Portugueses.

-- , Inhaca.

Dsikowitzky, Larissa, Sebastian Ferse, Jan Schwarzbauer, Tanja Samita Vogt, and Hari Eko Irianto. "Impacts of Megacities on Tropical Coastal Environments - The Case of Jakarta, Indonesia." Marine Pollution Bulletin 110, no. 2 (2016): 621-623. doi: 10.1016/ j.marpolbul.2015.11.060.

Esri, DigitalGlobe, GeoEye, Earthstar Geographics, CNES/Airbus DS, USDA, USGS, AEX, Getmapping, Aerogrid, IGN, IGP, swisstopo, and the GIS User Community. 2017. World Imagery.

Favaro, Sabina. "Listening to the Cities. Thick Mapping as Inquiry: Cape Town." PhD dissertation, Istituto Universitario di Architettura di Venezia (IUAV), Venice, It., 2017.

Instituto Nacional de Estatística (INE). Indicadores demográficos. Maputo, Moçambique, 2007-2040.

IOC/UNESCO, IMO, FAO, and UNDP. "A Blueprint for Ocean and Coastal Sustainability. An Inter-Agency Paper Towards the Preparation of the UN Conference on Sustainable Development (Rio +20)." Paris: IOC/UNESCO, 2011.

IUCN. "Final Act of the International Conference on the Conservation of Wetlands and Waterfowl." Ramsar, Iran: International Conference on the Conservation of Wetlands and Waterfowl, 1971.

Kabii, T. "An Overview of African Wetlands." In Wetlands, Biodiversity and the Ramsar Convention: the Role of the Convention on Wetlands in the Conservation and Wise Use of Biodiversity, edited by A. J. Hails. Gland, Switz.: Ramsar Convention Bureau, 1997.

Kithiia, Justus, and Anna Lyth. "Urban Wildscapes and Green Spaces in Mombasa and Their Potential Contribution to Climate Change Adaptation and Mitigation." Environment \& Urbanization 23, no. 1 (2011): 251-265. 
Millenium Ecosystem Assessment. "Ecosystems and Human Well-Being: Wetlands and Water Synthesis." Washington DC: World Resources Institute, 2005.

Magalhães, Manuela Raposo. A arquitectura paisagista: morfologia e complexidade. Lisbon: Editorial Estampa, 2001.

- - , M.M. Abreu, Mário Lousã, and Nuno Cortez, eds. Estrutura Ecológica da Paisagem Conceitos e Delimitação - Escalas Regional e Municipal. Lisbon: ISAPress, 2007.

McHarg, lan L. Design with Nature. Second edition. Hoboken NJ, USA: John Wiley \& Sons, 1991; first ed.: 1969.

Mendes, Maria Clara. Maputo antes da independência - Geografia de uma cidade colonial. Edited by Instituto de Investigação Científica Tropical. Vol. 68 (1980); Memórias do Instituto de Investigação Científica Tropical. PhD dissertation, Lisbon: Universidade de Lisboa.

Meneses, M.P. "Tese de doutoramento sobre Maputo." Interview by Ana Beja da Costa, 2014.

Meyer, Han, and Steffen Nijhuis, eds. Urbanized Deltas in Transition. Amsterdam: Techne Press, 2014.

Mitsch William J., and James G.Gosselink. "The Value of Wetlands: Importance of Scale and Landscape Setting." Ecological Economics 35, no. 1 (2000): 25-33.

Momade, F., Ferrara, M., Tomás de Oliveira, J. 1995. Carta Geológica de Maputo. Maputo: Direcção Geral de Geografia e Cadastro de Moçambique.

PUMPSEA. Publishable Final Activity Repost. ICAT (with collaboration of CoET), 2008.

-- . Report on Government Policies, the Legar Framework, Their Efficiencies and Implementation. ICAT, KMFRI, NEMC, UEM, 2008.

Ribeiro, Orlando. Atitude e explicação em geografia humana. Porto, Port.: Galaica, 1960.

Roberts, Debra, Richard Boon, Nicci Diederichs, Errol Douwes, Natasha Govender, Alistair McInnes, Cameron McLean, Sean O’Donoghue, and Meggan Spires. "Exploring Ecosystem-Based Adaptation in Durban, South Africa: 'Learning-By-Doing' at the Local Government Coal Face." Environment \& Urbanization 24, no. 1 (2011): 167-195. doi: $10.1177 / 0956247811431412$.

Saranga, I., A. Sênvano, F. Momade, J. Tomás de Oliveira, and R. P. Dias. 2008. Notícia Explicativa da Carta Geológica 2632 B1 Catembe Escala 1/50 000. Edited by Républica de Moçambique Ministério dos Recursos Minerais. Moçambique: INETI, DNG, IPAD.

Sousa Morais, João. Maputo, património da estrutura e forma urbana. Topologia do lugar. Lisbon: Livros Horizonte, 2001.

Russi, D., ten Brink, P., A. Farmer, T. Badura, D. Coates, J. Forster, R. Kumar, and N. Davidson. The Economics of Ecosystems and Biodiversity for Water and Wetlands. Executive Summary. Institute for European Environmental Policy (IEEP) \& Ramsar Secretariat, 2013.

Turner, R. Kerry, Jeroen C.J.M. van den Bergh, Tore Söderqvist, Aat Barendregt, Jan van der Straaten, Edward Maltby, and Ekko C. van lerland. "Ecological-Economic Analysis of Wetlands: Scientific Integration for Management and Policy." Ecological Economics 35, no. 1 (2000): 7-23.

United Nations (UN). Agenda 21 United Nations Conference on Environment \& Development, 1992.

- - . The Sustainable Development Goals Report, 2016. Edited by Lois Jensen.

United Nations Convention on Biological Diversity (UNCBD). Summary of the Second Global Biodiversity Outlook, 2006.

United Nations Economic Comission for Africa (UNECA). African Strategies for the Implementation of the UNCED Agenda 21: a Proposal Executive Summary. Edited by United Nations. Economic and Social Council, 1993.

United Nations Educational, Scientific and Cultural Organization (UNESCO-MAB). "Unesco Man and Biosphere Programme." 1971. http://www.unesco.org/new/en/natural-sciences/ environment/ecological-sciences/man-and-biosphere-programme.

United Nations Environment Programme (UNEP). "Introduction and Conceptual Framework." In Ecosystems and Human Well-Being, a Framework for Assessment. Edited by Millenium Ecosystem Assessment, 2005.

UNEP-AEWA. "Agreement on the Conservation of African-Eurasian Migratory Waterbirds." 1996. http://www.unep-aewa.org/en/legalinstrument/aewa.

UNEP-CMS. "Convention on the Conservation of Migratory Species of Wild Animals." 1979. http://www.cms.int/. 
UNEP-RSP. "The Nairobi Convention.” 2010. https://www.unenvironment.org/explore-topics/ oceans-seas/what-we-do/working-regional-seas/regional-seas-programmes/easternafrica.

UNFCCC. "The Paris Agreement." 2017. http://unfccc.int/paris_agreement/items/9485.php.

\section{Acknowledgments}

The authors would like to thank the Portuguese Foundation for Science and Technology (FCT) for the PhD grant: SFRH/BD/101053/2014. This work was developed in LEAF (Linking Landscape, Environment, Agriculture and Food Research Centre) - Instituto Superior de Agronomia, Universidade de Lisboa (UID/AGR/04129/2013), financed by the FCT through national funds.

\section{Credits}

Figures 1 and 2: photos by the Author

Figures 3-9: maps produced by the Author, based on 1965 - 1967 Maputo District Military Map (DPSGC 1967, 1965, 1958b, a) and the 2017 ESRI ArcGIS (Esri, 2017).

Ana Beja Da Costa holds a degree in Landscape Architecture at the Instituto Superior de Agronomia (ISA), Portugal and received a post-graduate Master in Human Settlements degree from KU Leuven, Belgium. She participated in several research projects on landscape design and ecology applied to human settlements, namely in East Timor, India, Ghana and Mozambique. Furthermore, she has developed an international carrier as Landscape Architect. She holds a PhD research grant from Fundação para a Ciência e Tecnologia (Portugal). E-mail: anabejacosta@gmail.com

Luis Paulo Faria Ribeiro is a Landscape Architect, and holds a PhD from the University of Massachusetts. He is a founding partner of TOPIARIS and he has been teaching Landscape Theory, Planning and Design since 1999. He is also Head of the master's and PhD programs in the Landscape Architecture Department at ISA. He has been invited as lecturer at several universities, such as the University of Massachusetts, University of Santiago de Compostela, the University of Milan, Southeast University of China/Najing. He is co-founder of the Portuguese Greenways Association. E-mail: Iribeiro@isa.utl.pt 